\title{
Upaya Pemberdayaan Masyarakat dalam Bentuk Membangun Penangkaran Budidaya Ikan Lele untuk Membantu Perekonomian Warga di Desa Titi Baro Kecamatan Idi Rayeuk
}

\author{
Nadia Jaharuddin*1, Lu'luah², Ellida Novita Lydia ${ }^{3}$ \\ 1,2,3Teknik Sipil, Fakultas Teknik, Universitas Samudra, Indonesia \\ *e-mail: nadiajaharuddin04@gmail.com ${ }^{1}$, ahlulu412@gmail.com ${ }^{2}$
}

\begin{abstract}
Abstrak
Gampong Titi Baro adalah salah satu desa yang ada di Kecamatan Idi Rayeuk, Aceh Timur, Provinsi Aceh, Indonesia. Gampong Titi Baro merupakan salah satu gampong yang dipilih untuk melaksanakan kegiatan KKN Tematik Universitas Samudra, dengan judul KKN "Upaya Pemberdayaan Masyarakat Dalam Bentuk Membangun Perekonomian Warga Di Desa Titi Baro Kecamatan Idi Rayeuk". Kecamatan Idi Rayeuk memiliki potensi desa hasil laut, pertanian dan ikan air tawar. terdapat salah satu seorang pemuda menggemari bertenak ikan lele yang jadi masalahnya tempat kolam yang digunakan tidak efesiensi dan efektif. Oleh karena itu tim pengabdi mengembangkan budidaya ikan lele tersebut dengan kolam yang lebih efektif dan efisian. kegiatan ini merupakan program kerja utama dari kelompok KKN Tematik Gampong Titi Baro, dimana program ini merupakan salah satu kegiatan yang melibatkan masyarakat di desa tersebut. KKN Tematik ini bertujuan untuk meningkatkan potensi desa, salah satunya dengan memberikan cara budidaya ikan lele dengan tujuan dapat membantu perekonomian warga di Gampong Titi Baro. Adapun metode melaksanaan program kelompok KKN Tematik di Desa Titi Baro ini yaitu: Survey lokasi, pembersihan lahan, pembuatan rangka/bak/atap Kolam Ikan Lele, memasukkan Air dan Penebaran Benih Ikan Lele. Hasil pelaksanaan kelompok KKN Tematik 2021 di Desa Titi Baro, dapat ditarik kesimpulan yaitu telah melaksanakan program pembangunan infrastruktur kolam ikan lele. Dimana program tersebut dapat membantu upaya perekonomian Desa Titi Baro. Dan program tersebut juga mendapatkan respon positif dari perangkat desa dan masyarakat di Desa Titi Baro sehingga semua berjalan lancar.
\end{abstract}

Kata kunci: Desa Titi Baro, Kecamatan Idi Rayeuk, KKN Tematik

\begin{abstract}
Gampong Titi Baro is one of the villages in Idi Rayeuk District, East Aceh, Aceh Province, Indonesia. Gampong Titi Baro is one of the villages chosen to carry out the Thematic Community Service Program at Samudra University, with the title "Community Empowerment Efforts in the Form of Building the Economy of Residents in Titi Baro Village, Idi Rayeuk District". Idi Rayeuk sub-district has potential for marine, agricultural and freshwater fish villages. there is one young man who likes to raise catfish, the problem is that the pond used is not efficient and effective. Because the team is dedicated to developing the catfish farming with a pond that is more effective and efficient. this activity is the main work program of the Titi Baro Thematic Community Service Program group, where this program is one of the activities that involves the community in the village. The thematic KKN aims to increase the potential of the village. One of them is by providing a way of cultivating catfish with the aim of helping the economy of the residents in Titi Baro Village. The methods for implementing the Thematic KKN group program in Titi Baro Village are: site survey, land clearing, making the frame/tub/roof of the catfish pond, entering water and stocking catfish seeds. The results of the 2021 Thematic KKN group implementation in Titi Baro Village, it can be concluded that they have implemented a catfish pond infrastructure development program. Where the program can help the economic efforts of Titi Baro Village. And the program also received a positive response from village officials and the community in Titi Baro Village so that everything went smoothly.
\end{abstract}

Keywords: Idi Rayeuk District, Thematic Community Service Program, Titi Baro Village

\section{PENDAHULUAN}

Gampong Titi Baro adalah salah satu desa yang ada di Kecamatan Idi Rayeuk, Aceh Timur, Provinsi Aceh, Indonesia. Desa ini berada di sekitaran Pusat Pemerintahan Aceh Timur dan memiliki potensi hasil laut, pertanian dan ikan air tawar. Apabila ditinjau dari segi pekerjaan umumnya masyarakat Gampong Titi Baro bekerja sebagai petani, wiraswasta, 
pedagang dan nelayan. Desa ini dipimpin oleh seorang Geuchik yang bernama Muhammad Adam, SH. Gampong Titi Baro terdiri dari 3 Dusun yaitu: Dusun Blang Simpang, Dusun Blang Rayeuk, dan Dusun Blang Lhok. Secara geografis Desa ini merupakan wilayah yang berada di daerah dataran rendah. Gampong Titi Baro merupakan desa yang sebelah barat berbatasan dengan Desa seunebok Bacee, sebelah timur berbatasan dengan Desa Seunebok Teungoh, sebelah utara berbatasan dengan Seunebok Rambong dan sebelah selatan berbatasan dengan Kecamatan Darul Ihsan. Potensi daerah di Gampong Titi Baro adalah penghasil hasil laut, ikan air tawar dan pertanian. Terdapat salah satu seorang pemuda menggemari bertenak ikan lele yang jadi masalahnya tempat kolam yang digunakan tidak efesiensi dan efektif. Dikarenakan masyarakat disana masih termasuk awam dengan berternak ikan lele. Jadi, salah satu pemuda gampong titi baro membuat kolam lele dari kolam tanah atau bekas galian yang ukurannya pun tidak terlalu besar. Kolam tanah tersebut sangat tidak relative dan juga lokasi tempat kolam tersebut di dalam hutan, sumber airnya juga hanya dari hujan saja dan makanannya juga bukan khusus pakan ikan/sejenisnya. Maka dari itu, kelompok KKN Tematik Desa Titi Baro berinisiatif untuk membuat penangkaran kolam ikan lele dengan khalayak dan ekonomis serta dapat membantu perekonomian warga Titi Baro dengan penangkaran yang lebih bagus lagi dan lokasi lebih terjangkau sehingga masyarakat dapat ke kolam ikan tanpa harus pergi melalui hutan.

Adapun pelaksanaan kegiatan yang akan kelompok KKN Tematik Desa Titi Baro lakukan adalah Pembangunan Budidaya Kolam Ikan lele.

\section{METODE}

Dalam kesempatan ini, penulis akan menjelaskan tentang metode pelaksanaan KKN Tematik selama melaksanakan KKN Tematik di Desa Titi Baro. Adapun Metode Pelaksanaan KKN Tematik di Desa Titi Baro sebagai berikut:

a. Survey Lokasi Pembangunan Ikan Lele

Sebelum melakukan pembangunan kolam ikan, tim pengabdi terlebih dulu melakukan survey tempat untuk mengetahui ukuran kolam ikan yang akan di bangun.

b. Pembersihan Lokasi

Setelah melakukan survey lokasi, tim pengabdi memulai pembersihan lokasi dimana lokasi tersebut tempat untuk membuat kolam ikan lele dan meratakan tanah dilokasi tersebut menggunakan alat-alat seperti cangkul dan parang.

c. Pembuatan Rangka Kolam Ikan Lele

Setelah Pembersihan dan meratakan tanah, tim pengabdi melakukan pekerjaan perakitan rangka kolam menggunakan bambu yang berasal dari desa tersebut.

d. Pembuatan Atap dan Bak Kolam Ikan

Setelah Perakitan rangka kolam ikan selesai, tim pengabdi melanjutkan pemasangan atap dan bak kolam ikan lele menggunakan terpal.

e. Memasukkan Air dan Penebaran Benih Ikan Lele

Dan berikut nya sehabis pembuatan atap dan bak kolam telah selesai, kemudian tim pengabdi memasukkan air bersih menggunakan selang air selama 2 jam dan setelah air di kolam sudah tercukupi, kemudian benih ikan lele secara perlahan-lahan di sebarkan ke kolam ikan tersebut.

\section{HASIL DAN PEMBAHASAN}

Desa Titi Baro merupakan desa yang terletak di Kecamatan Idi Rayeuk. Desa tersebut memiliki potensi desa salah satunya hasil ikan air tawar yaitu ikan lele. Akan tetapi, ada kekurangan dalam membudidayakan hasil ikan lele tersebut, seperti tidak efektif nya kolam ikan yang jauh dari pemukiman warga. Disini penulis mengembangkan kolam tersebut menjadi kolam yang efektif dan efisen, serta dapat membantu perekonomian warga. 


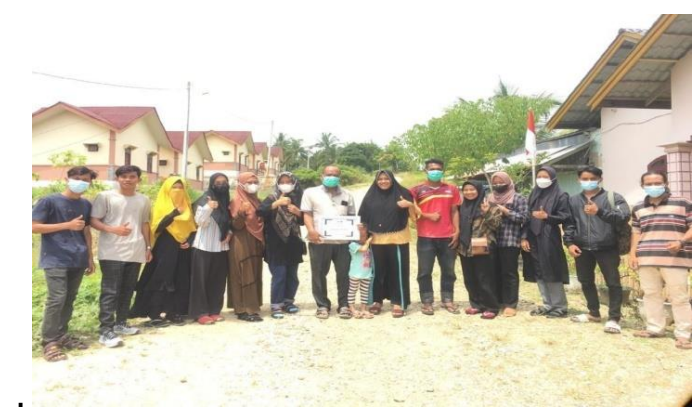

Gambar 1. Foto Bersama Setelah Selesai Program Kerja

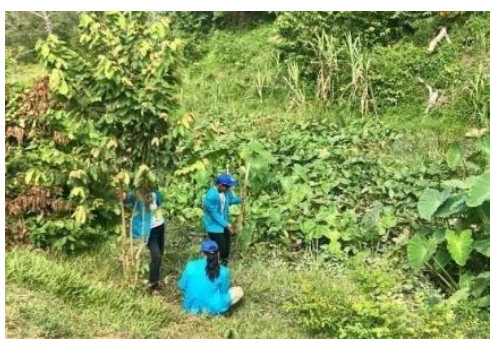

(a)

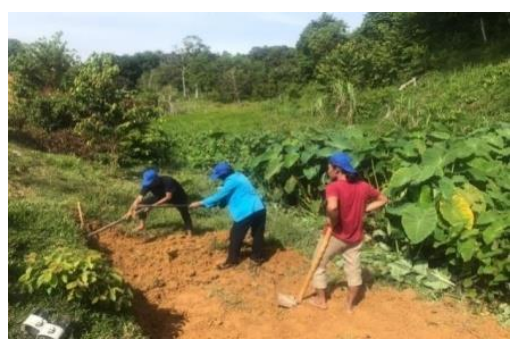

(b)

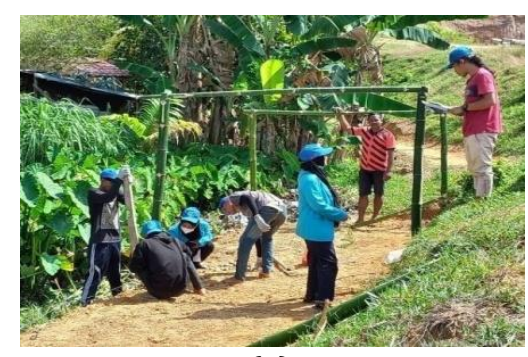

(c)

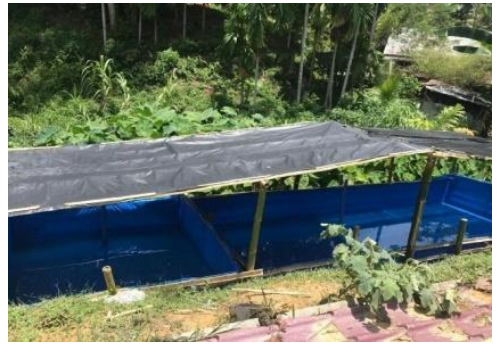

(d)

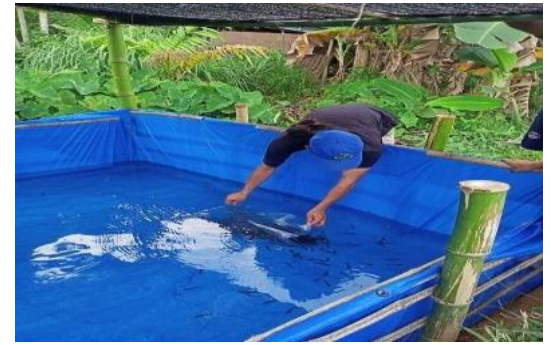

(e)

Gambar 2. (a) Survey Lokasi (b) Pembersihan dan Pengukuran Lahan (c)

Pekerjaan Rangka Kolam (d) Mengisi Air dan Diamkan Seminggu (e) Penebaran Benih

Dari pembahasan di atas tim pengabdi mendapatkan hasil dari program KKN Tematik ini yaitu: Masyarakat di Desa Titi Baro dapat meningkatkan hasil budidaya dari pembudidayaan kolam secara maksimal dibandingkan dari hasil kolam sebelumnya dan meningkatkan potensi di Desa tersebut dikarenakan budidaya ikan air tawar memiliki modal rendah dll.

\section{KESIMPULAN}

Hasil pelaksanaan kelompok KKN Tematik 2021 di Desa Titi Baro, dapat ditarik kesimpulan yaitu telah melaksanakan program pembangunan infrastruktur kolam ikan lele. Dimana program tersebut dapat membantu upaya perekonomian Desa Titi Baro. Dan program tersebut juga mendapatkan respon positif dari perangkat desa dan masyarakat di Desa Titi Baro sehingga semua berjalan lancar meski memiliki banyak rintangan.

\section{UCAPAN TERIMA KASIH}

Ucapan terima kasih diberikan Allah SWT yang telah memberikan kemudahan dalam segala kegiatan ini. Ucapan terima kasih dan penghargaan setinggi-tingginya juga disampaikan kepada Fakultas Teknik Universitas Samudra yang telah mengadakan Kuliah Kerja Nyata (KKN) Tematik. Terima kasih juga kepada masyarakat Desa Titi Baro yang telah memberikan respon positif pada program KKN Tematik ini, Terima kasih juga kepada teman-teman sekelompok KKN atas kerja sama yang baik selama kegiatan ini. 


\section{DAFTAR PUSTAKA}

Revy Safitri,dkk.2016. Kuliah Kerja Nyata (KKN) Tematik Upaya Pemberdayaan Masyarakat Dalam Penerapan Teknologi Tempat Guna Berbasis Lingkungan Dan Ekonomi Di Kecamatan Merawang Kabupaten Bangka Provinsi Kepulauan Bangka Provinsi Kepulauan Bangka Belitung Universitas Bangka Belitung

Margolang, N. (2018). Pemberdayaan Masyarakat. Dedikasi: Journal of Community Engagment, I(2), 87-99. https://doi.org/10.31227/osf.io/weu8z

Kurnia, M., Jaya, I., Jalil, A. R., Arya, N., \& Amin, S. (2020). KKN Tematik Pemberdayaan Masyarakat melalui Penerapan Teknologi Untuk Peningkatan Taraf Hidup Masyarakat Di Kecamatan Pulau Sembilan Kabupaten Sinjai. Jurnal Pengabdian Masyarakat Hasanuddin, 1(1), 1-9. https://journal.unhas.ac.id/index.php/ipmh/article/view/9579

Ii, B. A., Teori, A. D., Pengertian, T., \& Pembelajara, S. (2012). Kajian Pustaka Molucca Medica, 11(April), 13-45. http://ojs3.unpatti.ac.id.index.php,moluccamed

Syardiansah. "Peranan Kuliah Kerja Nyata Sebagai Bagian Dari Pengembangan Kompetensi Mahasiswa." JIM UPB (Jurnal Ilmiah Manajemen Universitas Putera Batam) 7, no. 1 (2019): 57. 